\title{
In Vivo and in Vitro Response of Human Branched Chain $\alpha$-Ketoacid Dehydrogenase to Thiamine and Thiamine Pyrophosphate
}

\author{
DEAN J. DANNER, ${ }^{(27)}$ FRANCES B. WHEELER, SANDRA K. LEMMON, AND LOUIS J. ELSAS II \\ Department of Pediatrics, Division of Medical Genetics, Emory University School of Medicine, \\ Atlanta, Georgia, USA
}

\section{Summary}

In a homozygous affected patient with maple syrup urine disease, pharmacologic doses of thiamine lowered urinary excretion of branched chain $\alpha$-ketoacids and stimulated branched chain $\alpha$-ketoacid dehydrogenase (BCKAD) in his peripheral blood leukocytes. Supplementation of his branched chain aminoacid restricted diet with $100 \mathrm{mg} / \mathrm{day}$ of thiamine eliminated recurrent episodes of ketoacidosis. These clinical responses were studied in vitro using mitochondrial inner membranes prepared from his cultured skin fibroblasts and those from another thiamine-responsive patient from Canada. BCKAD in both mutant cell lines had similarities to normal enzyme including: identical apparent $K_{m}$ value for thiamine pyrophosphate; similar heat inactivation profiles which were slowed by the presence of thiamine pyrophosphate; and stimulation above basal activity by thiamine pyrophosphate. Differences in the enzymes included: decreased apparent $V_{\max }$ for thiamine pyrophosphate; increased lability at $37^{\circ}$; and failure to respond to added $\mathrm{NAD}^{+}, \mathrm{CoASH}$, and $\mathrm{Mg}^{2+}$.

We propose that "excess" thiamine led to increased available thiamine pyrophosphate which stabilized the branched chain $\dot{\alpha}$ ketoacid dehydrogenase, decreased biologic turnover, increased enzyme specific activity and produced in vivo tolerance to branched chain aminoacids in these patients with maple syrup urine disease.

\section{Speculation}

By studying the partially purified normal and mutant branched chain $\alpha$-ketoacid dehydrogenases from cultured human fibroblasts, direct in vitro effects of thiamine pyrophosphate can be measured and related to in vivo clinical responses. This should improve and extend the treatment and management of patients with maple syrup urine disease and provide a method for study of other mutant human enzymes located in the mitochondrial membrane. 
The patient was dismissed from the facility and instructed to continue

Thiamine responsive maple syrup urine disease (MSUD) was first described in 2971. Oral loading with vitamin $B_{1}$ decreased previously elevated plasma branched chain amino ac1d concentrations in a presumably homozygous affected Canadian female child (22). In a preliminary study ve reported a similar effect from high doses of oral thiamine on two homozygous affected brothers $\alpha$-ketoacid dehydrogenase (BCKAD) which oxidatively decarboxy branched chain caproate (KIC), a-keto- $\beta$-methylvalerate (KMV) and $\alpha-k e t o$ sovalerate (KIV),
the transaminated products of leucine, isoleucine and valine respectively $(9,25)$. BCKAD is thought to be a multienzyme complex composed of a decarboxylase, a transacylase and lipoemide oxidoreductase in wh1ch thiamine pyrophoscentration of this cofactor can most likely be Increased by oral loading since thiamine kinase is active in the intestine and most other tissues of man (15. $17,18,23)$.

Vitamin responsive inborn errors of metabolism have been recognized for a number of years and our understanding of the mechanism by which these responses are realized continues to advance $(1,12,13,16,19,20,22)$. Classically, holoenzyme function was augmented by mass action through increased coenzyme production and binding to apoenzyme. In a more recently postulated mechanism, the presence of "excess" coenzyme decreased the degradation of holoenzyme $(12,13)$. Th1s mechanism was invoked as the means by wh1ch TPP improved BCKAD activity $(4,6)$. Supraphysiologic ingestion of thlamine 1ncreased BCKAD act1vity in normal adult $11 \mathrm{ver}$ by 2 fold, but required three weeks, the approx-
imate biological half life of mltochondrial turnover (4). Because BCKAD is expressed incultured human skin fibroblasts, and a decreased activity is observed in cells from MSUD patients, this tissue was used to study in vitro the
effect of TPP $(2-6,9)$. Here we report the effect of oral loading with thiamine on urine concentrations of the branched chain $\alpha-k e t o a c 1 d s$ and on enzyme function in isolated white blood cells from a single homozjgous affected patient. We also report studies on the effect of TPP on BCKAD activity in 1solated mitochondrial inner membranes from fibroblasts cultured from this thiamine responsive patient, the Canadian patient and normal controls.

\section{METHODS ARD MATERIAIS}

Following detailed description of the research project and obtaining informed parental consent, a homozygous affected MSUD patient was admitted to the Clinical Research Facility at Emory University where continuous supervision of his diet was possible. This patient's synthetic diet was restricted in branched chain amino acids and supplemented with Recomended Dietary Allowances of all vitamins including $5 \mathrm{mg} / \mathrm{day}$ of thiamine. After 1 week of stablilzation, the study was begun.. After no added thiamine, the diet was then supplemented with 50,100 and 150 mg of thlamine-HC1, respecday 1,3 , and 7 . each of four weekly periods. White blood cells were prepared from the unclotted blood using the polyvinyl pyrollidone method (20). These cells were used fresh for assey of the BCKAD activity.

Punch skin blopsy was used to obtain a primary culture of fibroblasts from this patient (Mutant A). Fibroblasts cultured from the previously reported thiamine responsive patlent were purchased from The Repository for
Human Mutant Cell Strains in Canada (Mutant B). Cells were grown in $690 \mathrm{~cm}^{2}$ Bellco roller bottles using Dulbecco-Vogt medium supplemented with $15 \%$ fetal calf serum. Cells were harvested when confluent, usually 7 days, by treatment with $0.25 \%$ trypsin for 30 minutes at $37^{\circ}$. Three to four roller bottles ylelded between 0.75 and $1.50 \mathrm{~g}$ wet welght of cells. The cells were made $0.1 \mathrm{mM}$ w1th respect to EDTA, hence MTE buffer, to a final concentration of $400 \mathrm{mg}$ wet welght per $10 \mathrm{mI}$ buffer. Protease VI was added at $2.5 \mathrm{\mu g} / 40 \mathrm{mg}$ vet weight and alloved to react for 7 minutes at $0^{\circ}$. At the end of this incubation, the cells were homogenized with a Blass-Tefion grinder and the volume
doubled with MTE buffer. Centrifugation at 700 og for 10 minutes separated undisrupted cells and nuclel from the mitochondria-contalning supernatant. Mitochondria were pelleted by centrifugation of this supernatant at 10,000 $x_{g}$ for 10 minutes. Mitochondria prepared by this method showed coupled respiration in the presence of succinate and ADP (5). This mitochondria rich pellet was treated with 0.5 Hg digitonin per mg mitochondrial protein for 20 minutes at $0^{\circ}$. Detergent action was stopped by the addition of MTI buffer equal to the suspending volume and Inner membrane vesicles pelleted by centrifugation at $10,000 \times \mathrm{xg}$ for $15 \mathrm{minutes}$. This inner membrane rich pellet
was suspended in $30 \mathrm{mM} \mathrm{K} \mathrm{PO}$ buffer $\mathrm{pR} 7.2$ to a concentration of 80 to 150 was suspended in $30 \mathrm{mM} \mathrm{K} \mathrm{PO}_{4}$ buffer $\mathrm{pH} 7.2$ to a concent
HE protein per ml for use as the enzyme source $(5,21)$.

\section{ASSAY}

Urinary ketoacid concentrations were determined as their methyl derivatives by 6 as chromatography $(7)$. Fnzyme activity was assessed by liquid scintilfation of ${ }^{14} \mathrm{CO}_{2}$ released from the $1-{ }^{14} \mathrm{C}$ labeled ketoacid prepared from the $1-{ }^{-} \mathrm{C}$ labeled precursor amino acid as previously described (8). Incubs-
tion at $37^{\circ}$ was for the indicated times in the legends to figures and tables.

\section{HEAT INACTIVATION}

Aliquots of 1solated mitochondrial 1nner membranes were placed in a water bath at the indicated temperature for the appropriate time, with intermittant shaking to prevent superheating. The samples were then placed on Ice until assay. Cofactors were present or absent as 1ndicated. A minimum of $100 \mathrm{\mu g}$ of protein were used for aliquots. Protein was determined by the method of Lowry using bovine serum albumin as a standard (14).

Data analyses were alded by computer programs. All reagents were of highest purity available and made up in deionfed water.

RESULTS

In order to evaluate the blochemical response of MSUD patients to oral loading with thiamine, urinary output of the $\alpha$-ketoacids was monitored along w1th BCKAD activity in 1solated white blood cells. Flgure I summarizes the in vivo response. The upper panel demonstrates reduction in urinary a-ketoand excretion acid restricted diet at 1.25 gm protein per pound body weight, the patient excreted $199 \pm 80$ and $194 \pm 18 \mathrm{mg}$ per $24 \mathrm{hr}$ of a-ketolsocaproic and a-keto8-methylvaleric acids respecti \pm ely. After 3 weeks of supplemental thiamine
these values had fallen to $34 \pm 19$ and $42 \pm 18 \mathrm{~ms}$ per $24 \mathrm{hr}$. The lower panel these values had fallen to $34-19$ and $42-18 \mathrm{~ms}$ per $24 \mathrm{hr}$. The lower panel
represents the effect of oral thiamine on perlpheral leukocyte BCKAD. To represents the effect of oral thiamine on perlpheral leukocyte BCKAD. To normalize the enzyme data, a single control Individual was used who was maintained on Recommended Dletary Allowance doses of thiamine and a normal boxylation was $4.7,2.3$, and $5.5 \%$ or control, respectively. After thiamine
these values rose to $25.7,16.6$ and $23.0 \%$ of the same control. daily oral doses of $100 \mathrm{mg}$ thiamine. After three years on thiamine therapy, the patient was again admitted to the Clinical Research Facility for reevaluation. Thiamine above Recommended Dietary Allowance level was removed from his diet for three weeks and urinary branched chain $\alpha$-ketoacid excretion and peripheral white blood cell BCKAD activity was assayed. Both $24 \mathrm{hr}$ urinary excretion and BCKAD activity on admission was the same as day 28 of the initial patient's monthly ketoacidosis of unknown cause disappeared and for six years the patient has remalned stable on the restrictive diet, supplemented
with thiamine at $100 \mathrm{mg} / \mathrm{day}$ and has required no further hospitalizations for treatment of metabolic acidosis.

Since the activity of the dehydrogenase was reflected in cultured skin fibroblasts, this tissue was used to 1nvestigate the mechanisms producing the observed clinical responses to high doses of thiamine. Isolated inner eliminated complicating variables in branched chain a-ketoacid decarboxylation such as membrane transport of substrates and cofactors and transamination of aminoscid precursors. Data of Johnson and Connelly with beef liver mitochondria suggested that the branched chain $\alpha$-ketoacid dehydrogenase was localized on the outside of the inner membranes, facing the intramitochondrial space (11). When the outer membrane was removed by digitonin treatmas made directly accessible to the substrate and cofactors.

When these membrane preparations were incubated at $37^{\circ}$ without exogenous cofactors followed by a 15 minute assay, ${ }^{4} \mathrm{CO}_{2}$ release from the $\alpha$-ketoac1ds became dependent upon the addition of cofactors during the assay. The most important cofactor to eliminate was thiamine pyrophosphate since the
fall to beseline activity did not occur if this cofactor alone were added to the buffer (5). The left panel in figure 2 shows that BCKAD from normal fibroblasts fell to basal activity after 90 minutes. Without exogenous cofactors during the assay, activity was only $3 \%$ of that found after 5 minutes of incubation. The 5 minute time point reflects the temperature equilibra tion period used in all experiments and was used as our zero time point. When all four cofactors were present during the 15 minute assay, full restoration of act1vity was possible. The right panel describes a similar effect with mutant enzyme. In contrast to normal enzyme, after 90 minutes $1 t$ was only possible to restore $34 \%$ of the mutant enzyme activity by the 30 mion of cofactors. Full restoration of $\mathrm{CO}_{2}$ release was possible at the mutant enzyme complex appeared more sensitive to lncreasing duration of preincubation reflecting an increased lability at $37^{\circ}$.

Cofactors were then tested singly and in combination for their ability to restore decarboxylating activity to the protelns in inner mftochondrial membranes. All possible combinations were tested but only the results of the most pertinent data are reported in Table I. Ninety minutes of Incubation was used to lower $\mathrm{CO}_{2}$ release to basal level. Again, note that the absence of thiamine pyrophosphate during this preinfubation was necessary to preincubation and assay, BCKAD from normal cells was malntained at 18 fold above basal level. Thls was not seen for enzyme from the mutant cells. When thiamine pyrophosphate was aded along with the other cofactors during the assay period, an additional 3 fold stimulation was observed with normal enzyme and a sfmilar effect was now seen with BCKAD from the mutant cells. Identical results were seen with mutant $A$, data not shown.

The response to added TPP after 90 minutes incubation wi thout cofactors made it possible to compare affinity. constants for thiamine pyrophosphate in the mitochondrial inner membrane preparations from mutant and normal cell lines. Double reciprocal plots of velocity versus thiamine pyrophosphate con-
centrations w1th saturating concentrations of $\mathrm{KIC}$, NAD ${ }^{+}$, CoASH and Mg ${ }^{+}$showed a common apparent $\mathrm{K}_{\mathrm{m}}$ Ylalue of $1.6 \mathrm{\mu M}$, figure 3 . Apparent $\mathrm{V}_{\mathrm{m}}$ values were 400 and 180 pmoles $14 \mathrm{CO}_{2} / \mathrm{mg}$ protein $/ 15$ minutes for mutants $B$ and $\mathrm{A}$ respectively. These findings 1ndicated that both mutants had a decreased apparent $\mathrm{V}_{\mathrm{m}}$ for thiamine pyrophosphate and the two fold higher overall act1vity expressed by the Canadian patient (Mutant B) as compared to the Georgian (Mutant A) might reflect their clinical findings of a more
for the Cansdian patlent when compared to the Georgian.

Heat inactivation can often distingulsh a mutant enzyme from its normal counterpart. This was not true in our inner membrane preparations. When denaturation at $50^{\circ}$ with time was measured, identical rates of inactivation
were observed in the mutant and normal membrane preparations (Figure 4). were observed in the mutant and normal membrane preparations (Figure 4).
Of Interest, however, was the stabilizing effect of thiamine pyrophosphate on these rates of inactivation. When thiamine pyrophosphate was included during the heating process, the inactivation rate was retarded in a simllar manner for normal and mutant. $T_{3}$ for normal $B C K A D$ went from $5 \mathrm{~min}$ without thiamine pyrophosphate to 10 min if the presence of thiamine pyrophosphate and for mutant BCKAD the respective times were 6 and 12 min.

\section{DISCUSSION}

These data explore the mechanism of vitamin response and expand an earlier report from Canada about a thlamine-responsive patient with MSUD who had decreased plasma branched chain amino acids in response to high oral doses of thiamine (22). A response to thiamine in pharmacological acids and an 1ncrease in BCKAD activity in isolated white cells. Initially, acids and an increase in BCKAD activity in isolated white cells. Initially, the patient's condition was controlled by dietary restriction of the branched chain amino acids which maintained urinary ketoacid excretion at approximatethe output of these ketoacids was further reduced and has remained at these lowered levels for six years. In addition, the specific activity of his perpheral leukocytes BCKAD increased at least 5 fold during this treatment
period and suggested that improved enzyme function was the direct effect of period and suggested that improved enzyme function was the direct effect of pharmacological doses of thiamine. It was found previously that the spect oral loading with thiamine (4). A cllnical hypothesis to correlate these oral loading with thiamine (4). A cllnical hypothesis to correlate these f1ndings suggests that greater intake of thiamine produced higher intra-
cellular concentrations of thiamine pyrophosphate, which increased the b10logical half ilfe of mitochondrial branched chain $\alpha$-ketoacid dehydrogenase. Acute effects of high-dose vitamin administration and removal would not be Acute effects of high-dose vitamin administration and removal would not be Georgla patient. Additionally, removal of high levels of thiamine from this peorgia patient. Additionally, removal of high levels of thiamine from petient's diet did not result in increased urinary ketoacid levels and decreased BCKAD activity in white blood

Direct biochemical data to explain the in vivo effect of high thiamine 
bound to Inner mitochondrial membranes of cultured human skin fibroblasts: Mitochondrial inner membranes prepared by treatent with digitonin resul in a 5 fold purlfication or BCKAb and ellminted the need for transmembran transport and conversion or predursors to cofactors and substrates before catalysis $(5,21)$. The use of these organelles as the enzyme source als which might compet for the exorenous cofactors and substrate.

Despite marked reduction in overall activity, BCKAD prepared in this wa y from MSUD mutant cells had seversl gimilar physical characteristic when compared to enzyme prepared from cells with normal BCKAD ectivity. Decarboxylation of the branched chain a-ketoacids by both normal and mutant enzymes was reduced to basal level by incubation for 90 minutes without exogenous coractors. Addition of TPP during this period prevented this fal in activity (5). Addition of TPP to both preparations at basal levels produced ${ }^{2+}$ three fold atimulation $\mathrm{in} \mathrm{CO}_{2}$ release in the presence of $\mathrm{NAD}^{+}$, CoAs normal and mutant BCKAD occurred within 15 minutes at $50^{\circ}$. This rate was slowed and $T_{z}$ doubled by including thiamine pyrophosphate during heating in both the normal and mutant preparations indicating that thiamine pyrophosphate produced thermostability. Finally, an apparent $K_{m}$ value of $1.6 \mu \mathrm{M}$ for thiamine pyrophosphate binding in BCKAD was identical for the enzyme from mutant and normal cells indicating a similar affintty for this cofactor.

Important differences were found for the BCKAD from these mutants as compared to the enzame from control cells. The maximal rate of $\mathrm{CO}_{2}$ release at saturating concentrations of thiamine pyrophosphate $\left(v_{m}\right)$ was greatly reduced for the two mutant enzymes studied. Since binding for thiamine pyrophosphate was normal $\left(K_{m}\right)$ we suggest that the first protein in the complex, decarboxylase, functions normally in substrate and cofactor binding. Thus, decreased activity would have to be due to an abnormallty in association of the component proteins, an abnormal catalytic site in one of the other two components or decreased number of functioning decarboxylase subunits. The concept of unstable protein-protein interaction is supported by the fact that the normal BCKAD could be reconstituted by the addition of NAD ${ }^{+}$, COASH and $\mathrm{Mg}^{2+}$ without thiamine pyrophosphate while both mutant complexes were

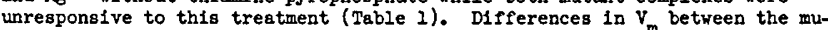
tants were reflected in the in vivo study where it was. reported that. the. Canadian patient required only $10 \mathrm{mg}$ thiamine per day for an acute lowerlng. of plasma branched chain aminosclds whlle in this study $100 \mathrm{mg}$ thlamine/day was determined to be necessary and required three weeks for maximsl effect. It has also been reported that the Canadlan patient had $40 \%$ of normal BCKAD activity with $0.1 \mathrm{mM}$ isoleucine but approached normal w1 th $5 \mathrm{mM}$ substrate (22). Enzyme activity from the Georgia patient has never exceeded $25 \%$ of control. This suggests that different mutations are responsible for these two MSUD phenotypes.

These results do not provide clear, simple answers to the mechanism by which thiamine was able to 1mprove the phenotypic expression of MSUD in these two patients. They do suggest that the mutation does not involve the transmembrane transport of thiamine, 1ts conversion to thiamine pyrophosphate or 1ts binding to the decarboxylase protein. Several other possibilities for the thlamine effeit exist. We know that thlamine pyrophosphate functions as the acceptor molecule for the acyl molty (24). Th1s primary role may be limited in a mutant multienzyme complex. A secondary role for thiamine pyrophosphate might be to aid in the proper alignment of component proteins. This role was demonstrated for thiamine pyrophosphate with becterlal pyruvate decarboxylase (10). Since BCKAD from mutants $A$ \& $B$ had decreased activity $\left(V_{m}\right)$ at saturating levels of thiamine pyrophosphate the larger amounts of this cofactor could be necessary for optimum component assoclation. Thus, when thiamine pyrophosphate was present in quantity sufficient for total binding, then. proper association might result and lead to a more stable complex better able to catalyze this reaction. This postulate is supported by the fact that mutant enzyme was more labile at $37^{\circ}$ and thiemine pyrophosphate stabilized both normal and mutant $B C K A D$ at both $37^{\circ}$ and $50^{\circ}$. A stabilization
effect of $B_{6}$ on mutant cystathionine $B$-synthase has also been proposed $(12,13)$.

More direct answers concerning the specific mutant gene product may be obtained through immunologic stuaies. Currently, normal mammalian BCKAD is being purifled and antibodies raised to its component proteins. Inner mitochondrial membranes from MSUD mutant fibroblasts will then be studied by 1rmuno-histochemical methods in an attempt to specifically 1dentify the abnormal protein and record more precisely the effects of thiamine pyrophos-
phate on the blological rates of protein degradation.

\section{ACKNOWLEDGEMENT}

The authors wish to thank Dr. C.R. Scriver for allowing us to study the cultured skin fibroblasts from his patients. A special thanks also to menuscript.

\section{REFERENCES}

1. Ampola, M.G., Mahoney, M.J., Nakamura, E. and Tanaka, K.: Prenatel therapy of a patient with vitamin-B ${ }_{2}$ responsive methylmalonic aciduria. N. Eng. J. Med. 293:313 (1975).

2. Dancis, J., Hutzler, J., Snyderman, S.E. and Cox, R.P.: Inzyme activity in classical and variant forms of maple syrup urine disease. J. Pediat. 81: 312 (1972)

3. Danc1s, J., Janse, V., Hutzler, J. and Levitz, M.: The metabolism of leucine in tissue culture of skin fibroblasts of maple syrup urin disease. Biochim. Blophys. Acte. 77:523 (1963).

4. Danner, D.J., Dav1dson, E.D., Elsas, L.J.: Thiamine 1ncreases the speciflc activity of human liver branched chain $\alpha$-ketoacid dehydrogenase. Nature 254:529 (1975).

5. Danner, D.J. and Elsas, L.J.: Subcellular distribution and cofactor function of human branched chain $\alpha$-ketoscid dehydrogenase in normal and mutent cultured skin fibroblasts. Biochem..Med. 13:7 (1975).

6. Elses, L.J. and Danner, D.J.: Effect of thiamine on normal and mutant human branched chain a-ketoacid dehydrogensse, In C.J. Gubler, M. Fujiwara, P.M. Dreyfus eds. Thiamine, Wiley Interscience, New York, 2976.

7. Elsas, L.J., Pask, B.A., wheeler, F.B., Perl, D.P. and Trusler, S.: Classical maple syrup urine disesse: Coenzyme resistance. Metob. 르: 929 (1972).

8. Elsas, L.J., Prlest, J.H., Wheeler, F.B., Danner, D.J. and Pask, B.A. Maple syrup urine disease: Coenzyme function and prenatal monitoring. Metab. 23:569 (1974).

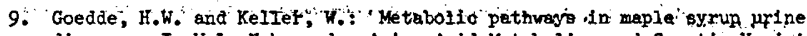
disease. In W.L. Nyhan ed. AmIno Acid Metabolism and Genetic Variation.
McGraw-Hill, New York, 1967.

10. Gounaris, A.D., Turkenkopf, I., Civerchis, L.L. and Greenlie, J.: Pyruvate decarboxylase III. Specific restrictions for thiamine pyrophosphate in the protein association step, subunit structure. Biochim. Biophys. Acte. 405:492 (1975).

11. Johnson, W.A. and Connelly, J.L.: Cellular localization and characterization of bovine liver branched chain a-ketoacid dehydrogenase. Blochem1Btry 11: 1967 (1972).

12. Kim, Y.J. and Rosenberg, L.E.: On the mechanism of pyrodoxine responsive homocystinuria II. Properties of normal and mutant cystathionine B-synthase from cultured fibroblasts. Proc. Natl. Acad. Sc1. 11:4821
$(1974)$.

13. Longh1, R.C., Fleisher, L.D., Tallan, H.H. and Gaull, G.E.: Cystathionine B-synthase deficiency: A qualitative abnormality of the def
modified by vitamin B6 therapy. Pediat. Res. $11: 100$ (1977).

14. Lowry, O.H., Rosebrough, N.J., Farr, A.I. and RandaIl, R.J.: Protein measurement with Folin phenol reagent. J. Biol. Chem. 193:265 (1951).

15. Morrison, A.B, and Campbell, J.A.: Factors influencing the excretion of oral test doses of thlamine and riboflavin by human subjects. J. Nutr. 72:435 (1960).

16. Mudd, s.H.: Pyridoxinemrespons1ve genet1c disease. Fed. Proc. 30: 970 (1971).

17. Nose, Y., Iwashima, A. and M1shimo, H.: Thiamine uptake by rat brain slices, in C.J. Gubler, M. Fuj1wark, P.M. Dreyfus eds. Th1amine, Wiley Interscience, New York, 1976.

18. Rindi, G. and Ventura, U.: Thiamine intestinal transport. Physiol. Rev. 52:821 (1972).

I9. Rosenberg; I.E.: VItamin-dependent genet1c disease,, in V.A. McKus1ck and R. Claibourne: Medical Genetics. H.P. Publishing Co. Nev York, 1973.

20. Rosenberg, L.E., Lilljequist, A.C. and Hsia, Y.E.: Methylmalonic ac1duria: Metabolic block localization and vitamin $B_{12}$ dependency.
Stience 162:805 (1968).

21. Schnaitman, C. and Greenawalt, J.W.: Enzymatic properties of the inner and outer membranes of rat liver mitochondria. J. Cell. B10l.
38: 158 (1968).

22. Scrtver, C.R., Clow, C.I., Mackenzie, 8. and Delvin, E.: Thlamine responsive maple syrup urine drsesse. Lancet 1. 310 (1971).

23. Sharma, S.K. and Quastel, J.H.: Transport and metabolism of thiamine in rat brain cortex 1n vitro. Biochem. J. 24:790 (1965).

24. Ullrich, J., Ostrovsig, Y.M. Eyzaguire, J. and Halzer, H. Th1amine pyrophosphate catalyzed enzymat1c decarboxylation of a-oxoac1de.
V1t. Horm. 28: 365 (1970).

25. Westall, R.G., Dancis, J., and Miller, 8.: Maple sugar urine disease a new molecular disease. Am. J. D1s. Child. 24:571 (1957).

26. Informed consent was obtained from parents of all children used in this study.

27. Requests for reprints should be addressed to: Dean J. Danner, Ph.D. Department of Pediatrics, Division of Medical Genetics, Emory University School of Medicine, Box 23344, Atlanta, Georgia, 30322.

28. Louls J. Elsas, II, M.D. Is a recipient of a Career Development Award from Child Health and Human Development, NIH HD 35615. This work was supported by NIH Grant HD 08388 from Child Health and Human Development and a Clinfcal Research Center Grant 00039.

29. Recelved for publication August 22, 1977.

30. Accepted for publication November $16,1977$.

TABLE I. REQUIRDMETT POR TPP TO RESTORE BRAMCHED CHAIN Q-KETOACID DEHYDROCENASE ACYIVITY TO YITOCHONDRI
INEER MBMPANES RROM CULIURED SKIN TIBROBLASTS

\begin{tabular}{|c|c|c|c|}
\hline $\begin{array}{l}\text { CONDITIONS } \\
\text { OF 90 MIN. } \\
\text { PREINCUBATIOR }\end{array}$ & $\begin{array}{l}\text { COMDITIONS } \\
\text { OF } 15 \text { MIM. } \\
\text { ASSAY }\end{array}$ & CONTROL & MUTANT (B) \\
\hline & & P MOLES ${ }^{14} \mathrm{CO}_{2}$ & PROTETN/15' \\
\hline $\begin{array}{c}\text { No } \\
\text { ADDITIONS }\end{array}$ & $\begin{array}{c}\text { No } \\
\text { ADDITIONS }\end{array}$ & $53.13^{+}+12.61(4)^{\mathrm{b}}$ & $99.35=69.34(4)$ \\
\hline $\mathrm{NAD}^{+}$COASH${ }^{\mathrm{A}}$ & $\mathrm{NAD}^{+} \mathrm{COASH}^{\circ}$ & & \\
\hline $\mathrm{M}_{B}{ }^{2+}$ & $M_{g}{ }^{2+}$ & $971.91 \pm 64.12(5)$ & $78.13^{+}=17.09$ (3) \\
\hline $\operatorname{HAD}^{+} \operatorname{COASH}^{\mathrm{a}}$ & $\operatorname{TPP}^{*}$ & & \\
\hline $\mathrm{MB}_{\mathrm{B}}^{2+}$ & $\begin{array}{l}\mathrm{KAD}^{+} \mathrm{CASSH} \\
\mathrm{Mg}^{2+}\end{array}$ & $2564.45-74.63(3)$ & $266.75-9.82(3)$ \\
\hline
\end{tabular}

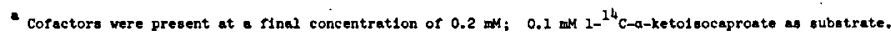

b Average \pm SBM for number of determination 1nd1coted in perentheses. 

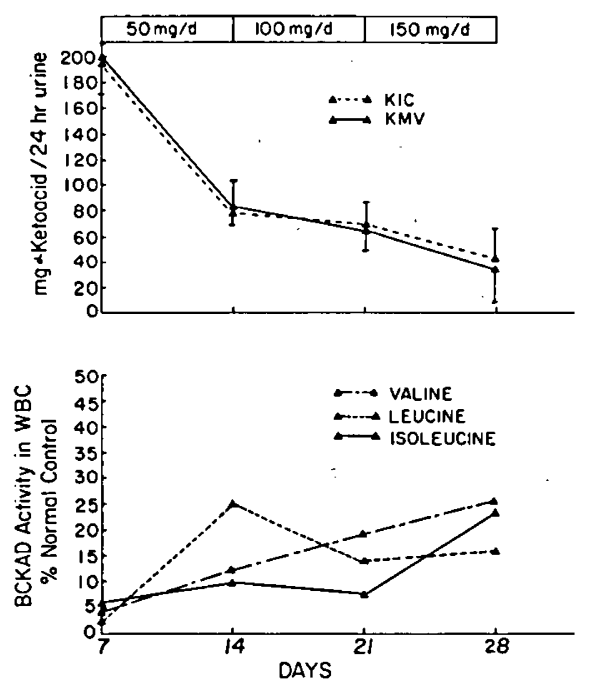

FIGURE 1 In vivo response of patient to oral loading with thiamine-HCI. Upper panel demonstrates the fall in urinary a-ketoacids during the test period. Values represent the average of 4 deteraluations \pm SEM. KIC $=$ a-ketoisocaproate, $\mathrm{KMV}=\alpha-k e t 0-\beta-$-Eethylvalerate. The lower panel represents the concomitant increase in branched chain a-ketoacid dehydrogenase (BCKAD) activity in isolated white blood cells during this same period. The values are an average of 4 determinations expressed as percent of activity in white blood cells from the same unaffected adult control prepared and assayed on the same day. Assay is described in Nethods and Materials.

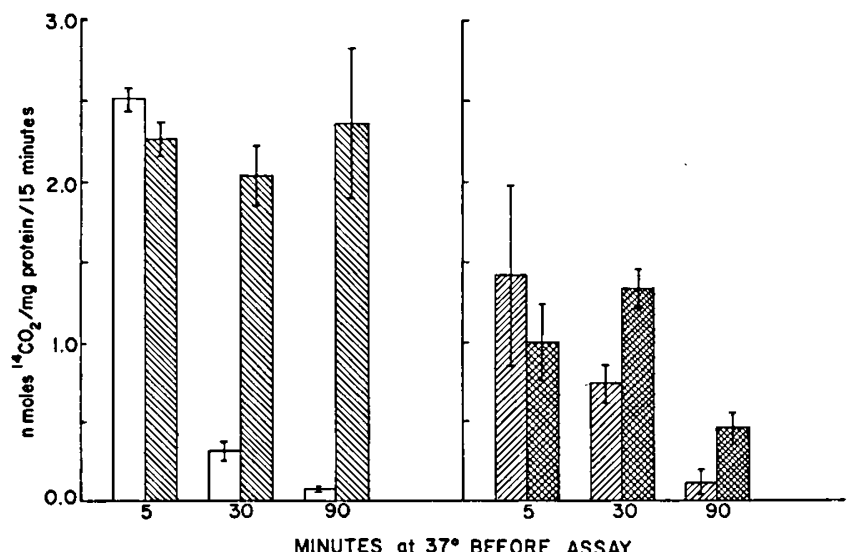

FIGURE 2 Reconstitution of branched chain a-ketoac1d dehydrogenase activity with mitochondrial inner membranes from control $D$, and

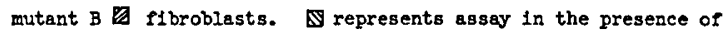
exogenous cofactors, during 15 minute assay. Data is the average of 6-8 deterninetions \pm SPM. Assay is as described in Methods and Mater1als,0.1 mM 1- ${ }^{14} \mathrm{C}-\alpha$-ketoisocaproate served as substrate.

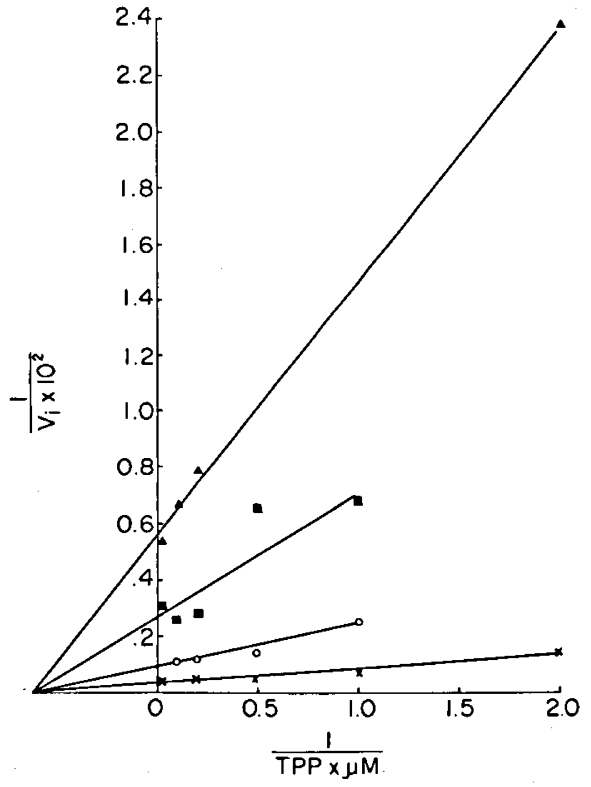

FIGURE 3 Lineweaver Burk plot of activity vs TPP concentration for branched chain $\alpha$-ketoacid dehydrogenase in mitochondrial Inner membranes 1solated from cultured skin fibroblasts. Tissue preparations were preincubated in $30 \mathrm{mM} \mathrm{K} \mathrm{PO}_{4}, \mathrm{pH} 7.2$ buffer for 90 minutes. Reactions were inftiated by addition of $I^{14} \mathrm{C}-\alpha-$ ketoisocaproate at $0.1 \mathrm{mM}$ and $\mathrm{COASH}, \mathrm{NAD}^{+}, \mathrm{Mg}^{2+}$ at $0.2 \mathrm{mM}$. TPP was present at the indicated concentrations and incubation was for 15 minuites. Data represent the average of $4-8$ determinations for each point. $\longrightarrow A, \square \longrightarrow$ mutant $A \& B$, respectively; $0-0$, $x-X=$ control.

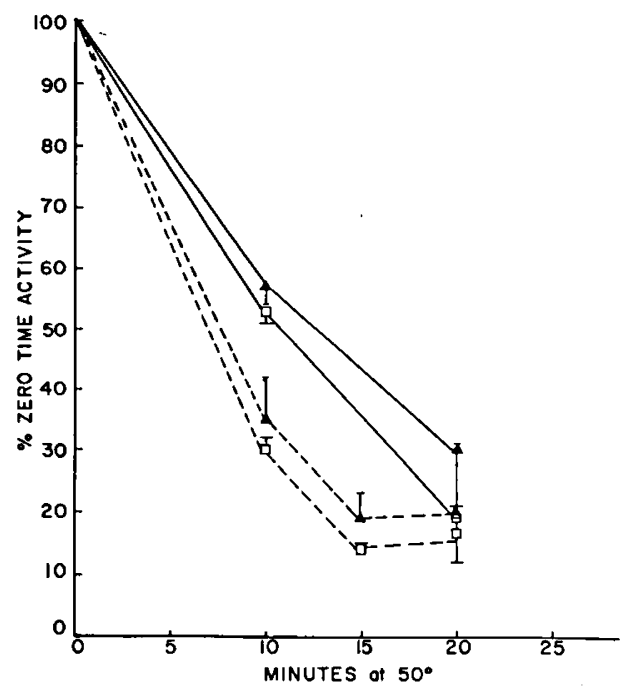

FICURE 4 Effect of heating mitochondriel inner membranes at $50^{\circ}$ on branched chain $\alpha$-ketoecid dehydrogenase in the absence (- - ) and presence (-) of $0.2 \mathrm{mM}$ thiamine pyrophosphate. Assay was for 15 minutes as described in text with all cofactors present during assay. $0.1 \mathrm{mM} 2{ }^{14} \mathrm{c}-\alpha$-keto 1socaproate served as substrate. Data 18 the average of 4 determinations and expressed as $\%$ of unheated sample $\square=$ Control; $\quad=$ Mutent A. 